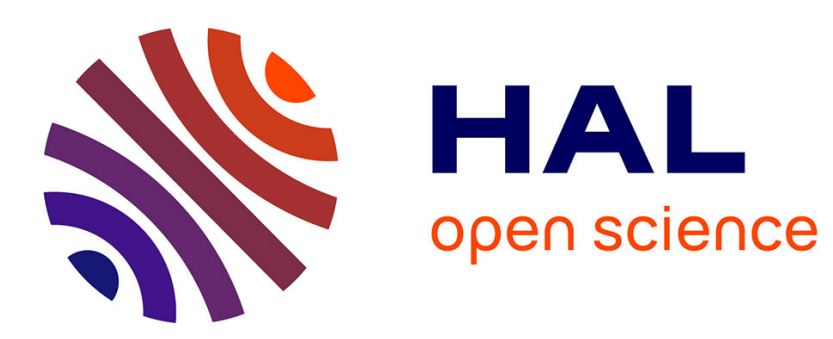

\title{
Time to treat metabolic acidosis in ICU with sodium bicarbonate? Maybe
}

Samir Jaber, Boris Jung

\section{To cite this version:}

Samir Jaber, Boris Jung. Time to treat metabolic acidosis in ICU with sodium bicarbonate? Maybe. Anaesthesia Critical Care \& Pain Medicine, 2018, 37 (6), pp.499-500. 10.1016/j.accpm.2018.11.006 . hal-02442618

\section{HAL Id: hal-02442618 \\ https://hal.science/hal-02442618}

Submitted on 18 Jan 2020

HAL is a multi-disciplinary open access archive for the deposit and dissemination of scientific research documents, whether they are published or not. The documents may come from teaching and research institutions in France or abroad, or from public or private research centers.
L'archive ouverte pluridisciplinaire HAL, est destinée au dépôt et à la diffusion de documents scientifiques de niveau recherche, publiés ou non, émanant des établissements d'enseignement et de recherche français ou étrangers, des laboratoires publics ou privés. 
Many physicians have ambivalence regarding the use of intravenous sodium bicarbonate administration as adjuvant "symptomatic" treatment in severe metabolic acidaemia in critical illness [1,2]. In a survey carried out in North America, two-thirds of the programme directors in nephrology or intensive care units (ICUs) declared that they used sodium bicarbonate for the treatment of acidaemia with hyperlactatemia [3]. We reported in a multicentre observational study [2] that sodium bicarbonate prescription was performed in $37 \%$ of patients with $\mathrm{pH}<7.20$, and it was very heterogeneous between ICUs and also between physicians working in a same ICU. Considering the nature of injury, the safety use of sodium bicarbonate with caution and the high mortality associated with severe metabolic acidaemia up to $60-70 \%$, this is somewhat surprising. Severe acidaemia can be critical, especially when an extremely low $\mathrm{pH}$ develops quickly. As emphasised in Joannes-Boyau and Forni's editorial [4], acidaemia is a syndrome, a consequence of an underlying pathology and therefore its correction can only be considered by treating the etiological cause. Thus, the causes of metabolic acidaemia in ICU patients are diverse, sometimes intertwined, and therefore cannot be all treated the same way.

Before, the publication of the BICAR-ICU trial [1] and the Zhang et al. trial [5], there was an absence of high-level evidence, leaving ICU clinicians uncertain whether sodium bicarbonate infusion is beneficial, ineffective, or indeed harmful to patients with severe acidaemia. It is claimed that sodium bicarbonate infusion may exacerbate intracellular acidosis because the $\mathrm{CO}_{2}$ produced in the extracellular milieu diffuses across the cell membrane more easily than ions, which might decrease myocardial contractility. Cooper et al. [6] administered sodium bicarbonate over 15 minutes and compared the effect on cardiac output over 30 minutes in lactic acidosis patients. They found no significant difference. Acidaemia also decreases the binding of norepinephrine to its receptors. It also shifts the oxyhaemoglobin curve to the right, allowing more $\mathrm{O} 2$ to be released-the Bohr effect. Few clinical studies reported in fact side clinical relevant effects.
Among the 389 patients with severe acidaemia $(\mathrm{pH}<7.20)$ included in the BICAR-ICU trial, no significant difference in the primary outcome was observed between groups (a composite of death by day 28 and the presence of at least one organ failure at day 7). However, several positive signals were reported in the BICARICU trial [1]. First, there were fewer deaths in the bicarbonate group than in the control group at day 28 with a $\mathrm{p}$ value equal to 0.07 . To reach the significance, an additional 50 patients would be necessary. Second, after multivariate analysis, sodium bicarbonate treatment was significantly associated with fewer deaths than no sodium bicarbonate treatment at day 28 (crude $\mathrm{HR} 0.783,95 \% \mathrm{CI}$ $0.0589-1.040 ; P=0.091$; and adjusted HR 0.727 , 95\% CI $0.540-$ $0.979 ; P=0.0356$ ). Third, sodium bicarbonate infusion decreased the need for renal-replacement therapy during the ICU stay. Fourth, in a predefined group of patients with concomitant acute kidney injury (AKI) (stage 2 or 3 of RIFLE or KDIGO) the use of sodium bicarbonate was associated with better survival and less renal replacement requirement. However, sodium bicarbonate infusion was associated with metabolic side effects such as hypernatremia, hypocalcaemia, and metabolic alkalosis, but none of these episodes were clinically relevant or reported as lifethreatening in the BICAR-ICU trial.

Zhang et al. [5] confirmed the results of the BICAR-ICU trial using a large US-based critical care database. In this retrospective observational study [5], sodium bicarbonate infusion was not associated with improved outcome in overall septic patients with metabolic acidosis, but it was associated with improved survival in septic patients with AKI stage 2 or 3 and severe acidaemia with a $\mathrm{pH}<7.20$.

The risk of not administering sodium bicarbonate to patients whose treatment is sodium bicarbonate administration is more important than administering sodium bicarbonate in patients whose indication is controversial. Indeed, sodium bicarbonate administration is recommended in case of loss of bicarbonate mainly due to two reasons, massive digestive fluid loss during diarrhea and kidney loss related to tubular acidosis or equivalent.

Although the BICAR-ICU trial is considered as a "negative" trial regarding the primary end point and the tested hypothesis (1); we believe, that BICAR-ICU trial [1] and the Zhang et al. study [5] give positive signals to consider sodium bicarbonate infusion in case of severe metabolic acidosis especially when it is associated with AKI. When sodium bicarbonate is infused, careful monitoring of kaliemia, sodium load and ionized calcemia must be done. 
However, further large randomised controlled trials are needed to confirm these positive results.

\section{Disclosure of interest}

S. Jaber: consulting fees from Drager, Xenios and Fisher \& Paykel. No COI for B. Jung.

\section{References}

[1] Jaber S, Paugam C, Futier E, Lefrant JY, Lasocki S, Lescot T, et al. Sodium bicarbonate therapy for patients with severe metabolic acidaemia in the intensive care unit (BICAR-ICU): a multicentre, open-label, randomised controlled, phase 3 trial. Lancet 2018;392(10141):31-40.

[2] Jung B, Rimmele T, Le Goff C, Chanques G, Corne P, Jonquet O, et al. Severe metabolic or mixed acidemia on intensive care unit admission: incidence, prognosis and administration of buffer therapy. A prospective, multiple-center study. Crit Care 2011;15(5):R238.

[3] Kraut JA, Kurtz I. Use of base in the treatment of acute severe organic acidosis by nephrologists and critical care physicians: results of an online survey. Clin Exp Nephrol 2006;10(2):111-7.
[4] Joannes-Boyau O, Forni L. Time to treat metabolic acidosis in ICU with sodium bicarbonate? Anaesth Crit Care Pain Med 2018.

[5] Zhang Z, Zhu C, Mo L, Hong Y. Effectiveness of sodium bicarbonate infusion on mortality in septic patients with metabolic acidosis. Intensive Care Med 2018.

[6] Cooper DJ, Walley KR, Wiggs BR, Russell JA. Bicarbonate does not improve hemodynamics in critically ill patients who have lactic acidosis. A prospective, controlled clinical study. Ann Intern Med 1990;112(7):492-8.

Samir Jaber M.D., Ph.D ${ }^{\mathrm{a}, \mathrm{b}, *}$, Boris Jung ${ }^{\mathrm{b}, \mathrm{c}}$ ${ }^{a}$ Anaesthesia and critical care department (DAR B), Saint Eloi, Montpellier university hospital, 34295 Montpellier, France ${ }^{\mathrm{b}}$ PhyMedExp, Inserm U-1046, CNRS, university of Montpellier, France 'Intensive Care Medicine, Lapeyronie, Montpellier university hospital, 34295 Montpellier, France

${ }^{*}$ Corresponding author. Inserm U1046, Saint Eloi ICU, Montpellier university hospital, Montpellier, France E-mail address: s-jaber@chu-montpellier.fr (S. Jaber). 